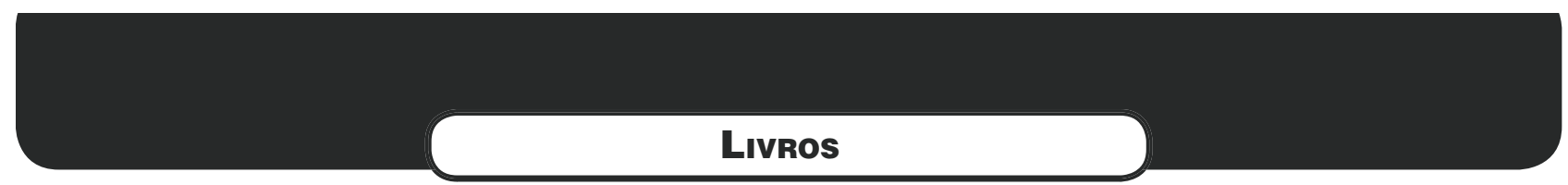

\title{
Abastecimento de Água para consumo humano
}

\author{
LÉo Heller e Valter LúCio de Pádua (organizaÇÃo)
}

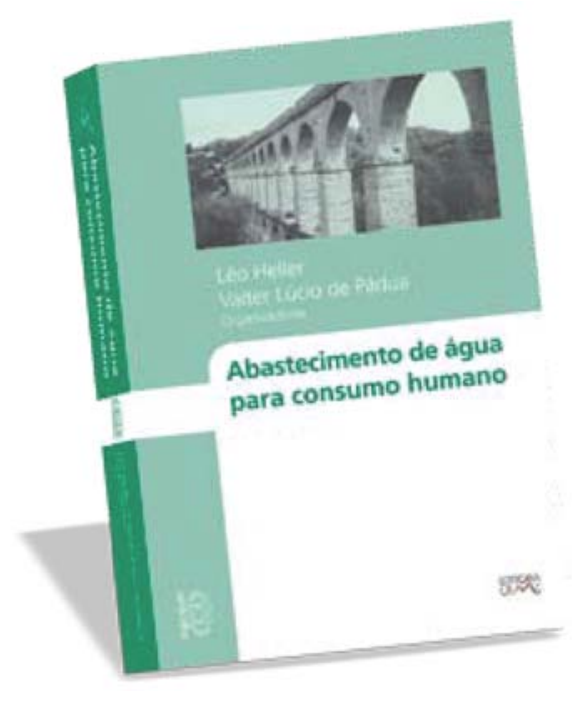

Durante algum tempo nossos profissionais da Engenharia Civil / Sanitária eram formados com referência em vários livros traduzidos. Muitos vão se lembrar (e talvez nunca tenham se esquecido), dentre outros, de Imhoff $\&$ Imhoff; Hammer; Fair, Geyer \& Okun; Metcalf \& Eddy; Babitt, Doland \& Cleasby. Depois assistimos a um florescimento do mercado técnico-editorial brasileiro com uma série de (bons) livros que acompanharam, e talvez ainda acompanhem, nosso dia-a-dia. Para continuar somente em água e esgotos, quem não estudou/consultou (estuda/consulta) Azevedo Netto, Dacach, Pacheco \& Jordão; os livros da CETESB?

Daí em diante, um certo hiato, até um novo boom editorial com várias publicações, as quais vieram atualizar e consolidar a expertise nacional, principalmente em tratamento de água e esgotos. E aqui são tantas e boas as publicações, que não me arrisco a nomeálas, até para não incorrer em omissões. Mas, a meu ver, uma lacuna deste hiato vem apenas mais recentemente sendo preenchida - a do abastecimento de água para consumo humano.

Neste sentido, Léo Heller \& Valter Lúcio de Pádua (ambos da Universidade Federal de Minas Gerais), acompanhados de vários co-autores do mais elevado gabarito, nos brindam com um livro da mais alta qualidade, abrangência e atualidade. Com qualidade técnica e editorial, atualizam, sistematizam e contextualizam o estado-da-arte em abastecimento de água para consumo humano em nosso tempo e lugar - a realidade brasileira.

Como um bom livro de engenharia, apresenta com rigor e detalhes as informações necessárias à concepção, ao projeto, implantação e operação de todas as etapas e partes constituintes de sistemas de abastecimento de água: escolha do manancial, previsão populacional e de consumo de água, técnicas de captação de água superficial e subterrânea, adução por gravidade e por recalque, reservação, tratamento (fundamentos) e distribuição de água, critérios para escolha de equipamentos, tubulaçôes e acessórios e muito mais do que é de se esperar de um bom livro. Rigor e detalhes são encontrados, por exemplo, na necessária abordagem multidisciplinar do tema (Hidráulica, Hidrologia, qualidade da água, consumo de água, aspectos construtivos, mecânica computacional, aspectos de saúde, dentre outros), na riqueza das ilustrações, exemplos e exercícios didáticos. Mas este livro traz também como grande mérito a atenção, com o mesmo rigor e detalhes, às chamadas soluçōes alternativas de abastecimento de água (ou as soluçôes individuais e as coletivas desprovidas de distribuição por rede).

Mérito porque tais soluções (ou melhor, seus usuários, que são muitos) merecem a mesma atenção da engenharia e dos engenheiros que as técnicas ou soluções mais complexas ou sofisticadas. Mérito e diferencial são encontrados ainda ao não se dissociar os aspectos já citados aos de gerenciamento e gestão de sistemas e serviços.

Destaca-se aqui a atenção ao gerenciamento de perdas e a discussão sobre os modelos de gestão vigentes no país. Enfim, trata-se de uma publicação que, sem esquecer a boa técnica, atenta às boas práticas de engenharia em toda a sua dimensão, tendo como "costura" de um conteúdo tão amplo a sustentabilidade dos serviços e sistemas de abastecimento de água.

Não tenho dúvidas em sugerir que este livro passa a compor a bibliografia essencial da Engenharia Sanitária brasileira e vai nos acompanhar (estudantes de graduação e pós-graduação, professores e profissionais envolvidos nos mais diversos aspectos do abastecimento de água para consumo humano) por muito tempo. A Engenharia agradece aos autores.

Comentários feitos por Rafael K. X. Bastos

Departamento de Engenharia Civil Universidade Federal de Viçosa

\section{Coordenador da coluna livrosi Prof. Gicero Onofre de Andrade Neto}

A sessão "Livros Técnicos", que a cada edição traz resumos comentados sobre livros de interesse na área, tem como principal objetivo permitir que o leitor, de forma rápida, se atualize e conheça o que há disponível no mercado editorial. As contribuiçōes deverão ser encaminhadas para: esa@abes-dn.org.br 